\title{
David S. Stern (ed.), Essays on Hegel's Philosophy of Subjective Spirit
}

\author{
Albany, NY: State University of New York Press, 2013, 266pp., \\ ISBN 978-1438444451
}

\author{
Reviewed by Kirill Alexandrov \\ Humboldt University, Berlin; Higher School of Economics, Moscow
}

Among the new tendencies in Hegelian studies today, an important (and highly welcome) one is the rediscovery of Hegel's Berlin philosophy of subjective spirit, a previously neglected part of his encyclopedic project (alongside the philosophy of nature, which is also starting to get more credit), which is to this day eclipsed by the masterwork that is the Jena Phenomenology of Spirit from 1807. The present volume of essays, edited by David S. Stern, is a testament to this new interest, comprising thirteen papers by established and upcoming scholars. Consisting of three divisions - "Anthropology," a doctrine of the human soul, sensation, individuality, and habit; "Phenomenology," a theory of consciousness, self-consciousness, and reason; and "Psychology," an account of spirit's theoretical (from representation to thought) and practical (from practical feeling and drive to happiness) faculties culminating in subjective freedom. Hegel's philosophy of subjective spirit not only encompasses a wealth of anthropological, epistemological, and other material, as well as pointing back to the philosophy of nature and forward to the philosophy of objective spirit, but also introduces a different logic of Geist's development compared to the Jena Phenomenology and a plethora of new, or differently conceptualized, topics and concepts-so many, in fact, that only a limited number of them come under consideration in the volume under review. And while the prominence of the Phenomenology is hardly going anywhere, and deservedly so, the philosophy of subjective spirit is not only worthy of engagement in and of itself, but also bound to shed additional light on the development of Hegel's phenomenological thought.

Two of the essays, by Marina F. Bykova and Robert R. Williams, focus precisely on an issue inherited from the Phenomenology-namely, the concept of recognition. While recognition has become a stock concept in and beyond Hegelian scholarship, there is, as Bykova observes, a "noticeable deficiency" when it comes to considering it "on the material of Hegel's Philosophy of Spirit" (139). Polemicizing with those who, like Habermas, 
Honneth, Hösle, and Peperzak, deny or downplay the importance of intersubjectivity in and for the system, Bykova argues that the "Self-consciousness" subsection of Phenomenology not only constitutes "a positive account of intersubjectivity... formulated in terms of the 'struggle for recognition'," but also treats intersubjective recognition as a vital and irreducible "condition of self[hood]" (141). Bykova convincingly traces the logic of self-consciousness from the I as "a creature of desire... aware of [its] difference from the object, the non-I" ${ }^{1}$ to the way its unity with the world "has to be mediated in and by other consciousness," marking the I's "openness" and realization that its desire can only be truly satisfied "not by an object, but by the other self-consciousness" (143-44). This recognition, however, is not instantaneous, but a torturous process which Bykova analyzes in detail and much of which overlaps with the familiar account of recognition in the Jena Hegel. Bykova's aim here, however, is not merely to reconstruct the logic of recognition in the Berlin phenomenology, but to drive home the crucial point that intersubjectivity is "necessitated by the very concept of self-consciousness" (148), so that "subjectivity and individuality are always intersubjectivity and communality" and "individuals are conscious of themselves only as 'universal' individuals" (150-51). Bykova concludes by distinguishing this "theoretical" principle of intersubjectivity from its "practical" realization in objective spirit.

Taking up the topic of recognition, Williams directs his argument against what he terms Robert Pippin's "historicist," "constructivist," and "left-Hegelian" account of recognition in Hegel (155). Agreeing on this with Bykova, Williams underscores the normative aspect of recognition for Hegel, to which Pippin is unable to do justice. Based on Hegel's texts and lectures on the philosophy of spirit from the 1820 s, Williams seeks to clarify how self-relation and relation to the other are reciprocally mediated. Despite the conceptual overlap with Bykova, Williams' analysis covers different ground thanks to its focus on "mediated self-actualization," its Aristotelian roots as well as its difference from Aristotle, and on how this concept helps us resist interpretations that collapse either the relation to other in Hegel into self-relation or the latter into the former. Crucially, Williams seeks to complement the master-slave analysis of recognition inherited from the Jena Phenomenology with an account of "the affirmative possibilities of recognition" that Williams finds in Hegel's 1825 lectures, contrasting "the reciprocal recognition constitutive of ethical life with the unequal coercive recognition constitutive of master and slave" (163). It is this positive recognition that Williams locates in Hegel's deduction of "the universal consciousness" (168), which progressively incorporates "the perspective of the other" (172). Another point of note here is the a contrario

As an aside, the Fichtean terminology of the "non-I" belongs to Hegel himself in the philosophy of subjective spirit, which generally happens to have more allusions to the Wissenschaftslehre than one perhaps might expect. 
way in which Williams defines the normativity of recognition-that is, in opposition to "misrecognition," or "the negations and distortions of recognition" undermining ethical life (157), which is, I believe, a helpful perspective on normativity in Hegel in general (Williams illustrates this point further by an analysis of Hegel's reading of Sophocles' Antigone). In order perhaps to push the importance of intersubjective recognition to the fore, Williams and Bykova consider "the universal consciousness" as essentially synonymous with spirit as such (168) and claim that the entire "deduction of the concept of spirit" is "laid down as the process of achieving the unity of self-consciousness" (142). I would take issue with these formulations given that, even if Bykova and Williams mean solely subjective spirit here, the latter culminates in the psychology, not the phenomenology, so that the deduction of spirit does not end once the unity of self-consciousness has been achieved, but goes forward to what Hegel terms the "free spirit."

Williams' emphasis on how the development of spirit can go wrong ties in well thematically with Hegel's anthropology and its account of madness. Three essays in this volume deal with madness, which has, alongside habit, traditionally been one of the most popular anthropological topics in Hegel scholarship. Glenn Alexander Magee's essay focuses on madness and the "paranormal" (such as Hegel's treatment of mesmerism or "animal magnetism"). What allows Magee to group these together is Hegel's conception of feeling as "the subjective way of knowing [that] dispenses wholly, or at least in part, with the mediations and conditions indispensable to an objective knowledge” (56, quoting §406Z. of the Encyclopedia). As animal magnetism shows, Geist is for Hegel not bound by space and time (66) and can "dispense with any mediation," a fact called "magic" by Hegel (56, quoting §405Z.). Magee goes on to consider the specifics of Hegel's explanation of mesmerism, in which the magnetizer's control over the magnetized can be explained by the fact that "in paranormal states the 'feeling' part of the soul temporarily usurps the higher-level, 'mental' functions" (60). Magee rightly sees this kind of usurpation as the general pattern of mental illness in the anthropology, which is also where madness comes into play. I would add that, for Hegel, this pattern is not only that of illness, but also of the unconscious as such, which he considers indispensable to the functioning of the human mind, and in that sense not abnormal. Here, the dividing line between the normative and the paranormal (or "irrational" [67], as Magee also calls it) becomes blurred and would perhaps necessitate a different conceptual distinction. In fact, one of the striking things about Hegel's anthropology is that it considers the "irrational" stratum of the human psyche as already "spiritual." Finally, on a more historical note, Magee's essay identifies an important source for Hegel's conceptualization of the paranormal, G. H. Schubert's Die Symbolik des Traumes (1814), which introduces two systems, the ganglionic and the cerebral, that "play opposite roles in the consciousness" and underlie "various forms of paranormal phenomena” (62-64). 
Nicholas Mowad's essay, also dealing with madness, connects Hegel's account of it with the dynamics of "sleeping and waking" in the anthropology (87). In other words, Mowad ties madness, which Hegel examines in "Feeling Soul," back to sleep and awakening, discussed in "Natural Soul." Insanity is, on this account, "the immediate identification of singular and universal" which is, however, distinct from mere sleep because, if it were identical to sleep, "an awakening would be required," which does not take place. Rather, madness is already "rooted in the awakening because in the awakening the soul is first posited as this individual soul." In contrast to sleep, madness presents an "attempt by the singular to stand on its own"but therein also lies its perversion (96). From the logical perspective that Mowad here adopts, in order to overcome madness, the division, or judgment (Urteil), between universal and singular must be mediated by a third term so it can be turned into a syllogism. This "mediating term" is habit. Mowad does not analyze the mechanism of habit as such in detail, but points out its function in the overcoming of madness, which consists in "cultivating in the madman feelings that the actual world, its relationships, and its obligations, have value and are not just an impediment to his (perhaps unrealizable) obsession" (98). Mowad's paper is short and does not cover the intersection of (self-)feeling, habit, and madness in Hegel in as much detail as I wish it would, but I generally think it is one of the most fascinating and well-argued essays in the volume, and should be a required reading for anyone trying to make sense of Hegel's anthropology.

Mario Wenning's paper also focuses on madness. It is also one of several papers in the present volume that argue for or assume a "naturalist" approach to Hegel's philosophy of spirit-which, given the general prominence of naturalism in philosophy of mind these days, should not come as a surprise. Wenning's position is that "free thinking [in Hegel] cannot be understood without a 'natural' dimension," so that Hegel is, in truth, not "an idealist who 'disenchants' nature and denigrates it to a mere preparatory stage in the development of spirit" (107). After discussing the tension between "the natural state of the soul" which is at the same time "unnatural" for Hegel, and pointing out Hegel's "discover[y of] the unconscious mind," Wenning turns to madness as not "the other of reason, but... a special form or dimension of reason" itself (109-11). In a move that remains somewhat unclear to me, Wenning identifies the "unconscious dimension" in the human mind to which madness appeals with the mind's "emerge[nce] out of nature" (111). I think Wenning's claim is too strong, and rests on a confusion between human nature and nature as such. Spirit as the human soul is for Hegel not Natur, but the Naturgeist, that is, the immediacy of spirit, not "nature qua nature" (112). It is unclear, too, why, in order "to enter into a conscious relationship to [nature]," spirit must identify with nature (113). At the same time, Wenning correctly notes that Hegel conceives of madness as "not categorically distinct from sanity," which "constitutes a break" with traditional eighteenth-century theories 
of madness (114). The account of madness that follows (referencing Kant and Foucault) is also helpful.

Italo Testa's essay also discusses Hegel's naturalism. Testa explains why the traditional problem of the soul-body relationship is categorically invalid for Hegel, the soul being, in Hegel's anthropology, embodied activity of sensation so that "soul" and "body" "refer to the same object, namely, the living individual" (23). He also distinguishes between "epistemological realism" and "metaphysical realism," arguing that Hegel endorses the former but not the latter (21). At the same time, Testa calls for "a broad conception of nature" to account for what he regards as "Hegel's naturalism" (24). Testa does not, however, engage with a wealth of textual material that makes any naturalist reading of Hegel problematic-such as Hegel's frequent insistence that spirit can begin only from spirit, or the fact that, for Hegel, even the first cry of a newborn human child is an act of spirit, etc., which seems to run contrary to Testa's and others' assumption that "Natural Soul" has to do with the non-human, animal part of the soul. Even the quotes that Testa brings in support of his argument, such as nature being a "presupposition" of spirit, do not seem to me to be self-evidently "naturalist.” Spirit can both have nature for its presupposition and not, as spirit, begin from nature; this is perfectly compatible with Hegel's idealism. In fact, "Natural Soul" does not, I believe, theorize the emergence of spirit from nature-it has to do, rather, with the spiritual significance of what is immediately given to and in the human soul. This givenness may itself emerge from nature; however, Hegel refuses to theorize this emergence, even when he discusses the soul's "natural qualities," focusing instead on their "spiritual meaning." For him, just as for German Idealism as a whole, spirit is a fact, and this facticity of spirit is non-emergent, resisting any naturalism (while also, in Hegel, avoiding dualism via the materiality of the body).

Furthermore, the soul as such (as universal ideality of life) may be common to both human and animal. However, the human soul has an entirely different logic, and it is in postulating this distinct logic of spirit, including the way it "idealizes" nature, that Hegel's idealist strategy lies. Pointing out, correctly, Hegel's emphasis on embodiment or the Naturgeist as immediacy of spirit does not seem to me to undermine it. Testa's move consists in anchoring spirit in nature, even if broadly conceived. (Hence also his emphasis on habit as natural, whereas Hegel himself introduces "second nature" as the individual's transformation of the "naturally" given.) I am, however, a bit suspicious of the "broad conception of nature" for which Testa calls, since its exact meaning remains unclarified. Finally, even if we were to grant that there are passages in which Hegel is a naturalist in a non-idealist sense, it would have been more fruitful, I believe, to confront these passages with those where he is not instead of just ignoring them altogether, as essays in this volume tend to do. It could be interesting, I believe, to consider the interplay of these two aspects or even to problematize the distinction between naturalism and non-naturalism itself. 
Skipping over Angelica Nuzzo's paper, which is a general introduction to Hegel' own introduction to the Philosophy of Spirit and his lectures on the same subject, as well as a summing up of Hegel's criticism of "rational psychology" and "empirical psychology," I will move on to Simon Lumsden's essay, focusing on the way habit "challenges the dualism of nature and spirit" (121). This dualism, however, is framed by Lumsden in terms taken not "immanently" from Hegel, but from Kant. It is Kant's "receptivity-spontaneity distinction" and its twin concept, the "mind-world division," that have, says Lumsden (122-23), informed much of post-Kantian debate, including more recently the work of Brandom, Habermas, Korsgaard, McDowell, and Pinkard. If, however, we look at habit in Hegel from this perspective, we can see that it eschews those categories and "challenges the dualism of the 'space of reasons' and the 'space of causes'” (122). Lumsden argues, further, that Hegel's account of habit is "a precursor" to the non-dualistic tradition that allows for "a rationality that is inscribed in cultural [or ethical] life itself, rather being authorized and legitimated by a single autonomous agent" or by "reflective acts of cognition by autonomous subjects" (12324). Habit transforms nature via self-positing, asserts a self-identity based on will, and establishes itself as the corporeal immediacy presupposed by spiritual activity as such. Lumsden concludes by saying that habit "is the way in which human beings can be at home with nature" (134); again, however, given that the "natural" in habit means its "immediate" characterhabit is the underlying immediacy of all activities of spirit-and especially given the transformative character of habit for Hegel, I am unconvinced that habit in Hegel has to do with "being at home" with nature as such. Lumsden's analysis itself, however, is clear and illuminating.

Two final essays on Hegel's anthropology are those by Jeffrey Reid and Jason J. Howard, both focusing on "Feeling Soul." Reid scrutinizes the difference between the 1827 and 1830 editions of the Encyclopedia and why the latter edition replaced the 1827 "Dreaming Soul" subsection of the anthropology with "Feeling Soul." Reid first traces the concept of the dreaming soul back to Hegel's psychological manuscript from 1794, after which he offers a consideration of what he takes to be the source of Hegel's notion of the dreaming/feeling soul, the Tübingen professor J. F. Flatt's lecture notes on empirical psychology. Having established that, Reid detects the cause of the change from the "dreaming" to the "feeling" soul, perhaps surprisingly, in the Hegel-Schleiermacher conflict and Hegel's opposition to what he viewed as the latter's "religion of feeling." If feeling takes priority over reason, this results for Hegel in madness, and Reid argues that, first, Hegel sees religious fervor as a form of mental pathology, and second, that his conception of said fervor is an implicit jab at Schleiermacher. In conclusion, Reid locates Hegel's motivation for intensifying the anti-Schleiermacher angle in the 1830 edition of the Encyclopedia specifically in his 1829 correspondence, where Hegel expresses his irritation with what he felt was an attack on the 1827 edition "by Schleiermacher and his Gefühlsschule” (49). 
Howard's essay, in turn, is devoted to the relationship between form and content in Hegel's picture of the emotions in the anthropology. Howard convincingly demonstrates that, on the one hand, Hegel has "a theory of emotions [that] is considerably innovative to the extent it anticipates many of the most pertinent distinctions in contemporary work on emotion" (71), in particular when Hegel differentiates emotions into different types and assigns to them a vital function in the transition to consciousness, in self-assessment, and in "moral character and self-worth." Howard also observes that "emotions are neither irrational nor "biologically primitive" but rather "integrative" for Hegel (80), which is, I believe, essential for understanding the rational ("spiritual" or "ideal") character of the anthropological in Hegel. On the other hand, despite his dialectical approach, Hegel still wants to maintain a "pronounced separation...between the form of emotions and their 'content" (81)-a position that, as Howard indicates, has been refuted by recent work on emotion, which has shown that "physiology plays little if any role individuating emotion types" (8182). Whether Howard is right or wrong in his view of Hegel on emotions depends on him being correct in claiming that "Hegel strongly implies that [the] differentiation [of inner feelings into emotions] happens before the reflexive will organizes and indexes the feeling," which in fact "cannot occur without some level of conscious integration" (82). In any case, Howard identifies the core of the problem very perceptively and opens up an interesting avenue for examining this issue further.

Two essays in the volume concern Hegel's "Psychology." Richard Dien Winfield's article undertakes to illuminate one of the most obscure and least studied sections of Hegel's Philosophy of Subjective Spirit, "Practical Spirit." Winfield sees the logic of "practical intelligence" contained in that section as elaborating the concepts of subjective will and free will, providing "the conceptual prerequisites for normative conduct," and "usher[ing] in the Philosophy of Objective Spirit" and the concept of right (201). To underscore the importance of the psychology's account of will, Winfield refers to the introduction to the Philosophy of Right, which "recapitulates the concluding section of the philosophy of [subjective] mind" (202), solidifying the latter's foundational role for the former. What it means for will to be practical intelligence, and how it is explicable in the context of Hegel's psychology, is the subject matter of Winfield's nuanced examination of the psychology as providing "the volitional prerequisites of rational agency" by considering "the forms of willing that lack full rationality" (207). The necessity of the pre-rational volition is shown by Winfield to be grounded precisely in the way Hegel derives the rational will from it, to which end Winfield discusses the three stage of practical intelligence, "Practical Feeling," "Impulses and Choices," and "Happiness," before comparing this logic with the perspective offered by the Philosophy of Right.

Referencing Herder's and Hamann's linguistic criticism of Kant in the "Metacritics," Jere O'Neill Surber offers an account of how Hegel's phi- 
losophy of language in the "Psychology" "both fills a conspicuous void in Kant's transcendental approach and delimits and counters the... metacritical skepticism" (182). In his overview of Herder's Metakritik, Surber concedes that the flaw of Kant's approach to cognition and thought consisted in his "wholesale dismissal of the role played by language"; however, metacriticism itself went too far, turning into "a thoroughgoing skepticism" regarding the possibility of speculative thought (184-85). Hegel's theory of language and signification, therefore, aims to navigate between these two extremes by assigning a mediating "systematic location" to language (186). On the one hand, Hegel makes language a constitutive presupposition and an irreducible element of the logic of "theoretical intelligence" in the psychology leading up to thought-a logic that goes from intuition to representation to thought, which Surber analyzes in detail (188-94). At the same time, however, this logic makes it clear that language and signification belong at the level of representation, not thought per se, and if we properly understand how names function as "pure linguistic determinations," we can see, according to Hegel, that language neither intrudes into thought nor subverts it as the skeptics claim. The "more limited" role that Hegel assigns to language, Surber concludes, helps him repel the metacritical attack and "avoid [metacritical] paradoxes," even though it also raises further issues regarding the importance of naming for Hegel's philosophy in general and his Logic in particular (195-96).

It is, of course, a bit of a shame that "Phenomenology" and "Psychology" only get two essays each, and for this reason, as well as due to the narrow scope of some of the essays and the emphasis on a limited number of topics, I do not think Essays on Hegel's Philosophy of Subjective Spirit can serve as a good introduction to, or overview of, the philosophy of subjective spirit for someone not already familiar with it. It is, rather, a typical academic volume addressed predominantly to Hegelian scholars or readers who already have a background in Hegel's philosophy of subjective spirit and can place these essays in a broader context. As such, it certainly serves its purpose and contains some very good papers. As someone who is not following current debates in analytic philosophy of mind, I cannot comment on how helpful this volume can be to analytic philosophers who are not scholars of Hegel. The last essay in the volume, by Philip T. Grier, may be the most useful in this regard, dealing as it does with two paradigms of the mind-nature relationship, the "narrow" and the "comprehensive"-the latter espoused by Hegel in his tripartite division of the philosophy of subjective spirit into soul, consciousness, and intelligence, and presenting these paradigms as two traditions in analytic philosophy of consciousness. There are, however, no Continental essays in this volume, which reflects the sensibilities of academic Anglophone philosophy departments at large. Overall, Essays on Hegel's Philosophy of Subjective Spirit is a useful and welcome book. It may feel a bit too one-sided and basic at times, but that merely goes to show that serious philosophical engagement with this side of Hegel is only just beginning. 